\title{
Review
}

\section{Cellular and Extracellular Regulatory Mechanisms of Hypothalamic Corticotropin-Releasing Hormone Neurons}

\author{
KeIICHI ITOI*,**, Audrey F. SEASHOLTZ**,***, ANd StAnley J. WATSON** \\ *The Second Department of Internal Medicine, Tohoku University School of Medicine, Sendai 980-8574, Japan, \\ ${ }^{* *}$ Mental Health Research Institute, ***Department of Biological Chemistry, University of Michigan, MI 48109, USA
}

\section{Introduction}

ALL living organisms are faced with changing interoceptive or exteroceptive stimuli ("stress"). Stress may be defined as any challenge to an organism which potentially changes its biological parameters from the basal values. All organisms are endowed with elaborate biological systems to maintain a stable internal milieu in the face of the stress, but in mammals, a primary component of this responsiveness involves the hypothalamicpituitary-adrenal (HPA) axis. All stress-related inputs are conveyed to the hypothalamus and integrated in the medial parvocellular division of the paraventricular nucleus (PVN), where a major proportion of corticotropin-releasing hormone (CRH) is synthesized [1-4].

$\mathrm{CRH}$, a 41-amino acid peptide, was first isolated from the ovine hypothalamus by Vale and colleagues [5]. The nucleotide sequences encoding the ovine [6] and rat [7] CRH cDNAs as well as the human [8], rat [9], ovine [10] and mouse CRH genes [11] have been determined. Hypothalamic CRH neurons project to the external layer of the median eminence where CRH is secreted into the portal blood in response to stressful stimuli. CRH then stimulates secretion of ACTH and synthesis of its precursor, proopiomelanocortin (POMC), in the anterior pituitary (for reviews, see [12, 13]). ACTH

This article was written as a memorial article for the Kawakami Prize of the Japan Endocrine Society, which was awarded to Dr. K. Itoi on May 31, 1996.

Correspondence to: Dr. Keiichi ITOI, The Second Department of Internal Medicine, Tohoku University School of Medicine, 1-1 Seiryo-machi, Sendai 980-8574, Japan then stimulates synthesis and secretion of glucocorticoids in the adrenal cortex. Glucocorticoids have wide-ranging and potent actions throughout the body, including changes in metabolism, immune function, vascular tone, and inflammatory responses. Circulating glucocorticoid levels are controlled by the inhibitory actions of glucocorticoid itself at pituitary and brain levels, thus forming a negative feedback loop.

The CRH neuron in the PVN plays a pivotal role in the regulation of the HPA-axis. Characterization of the brain mechanisms underlying the control of $\mathrm{CRH}$ neurons is critical for an overall understanding of how the HPA-axis helps to maintain the homeostatic balance of an organism. This review will focus, first, on the intracellular signaling pathways and the molecular mechanisms controlling CRH gene expression, and second, on the specific neuronal and humoral systems involved in the regulation of the $\mathrm{CRH}$ neurons.

\section{Intracellular Regulatory Mechanisms of CRH Neurons}

\section{CRH gene and the process of CRH synthesis}

The nucleotide sequences of the human [8], rat [9] and mouse [11] CRH genes are similar to each other, possessing high levels of homology in the $\mathrm{CRH}$ peptide-encoding sequence and the $5^{\prime}$ flanking sequence. The CRH gene has been mapped on the long arm of human chromosome 8 [14] and proximal region of mouse chromosome 3 [15].

The CRH gene contains two exons and one intron [8] (Fig. 1). The entire coding region of the CRH precursor is present in exon 2 . There are putative 

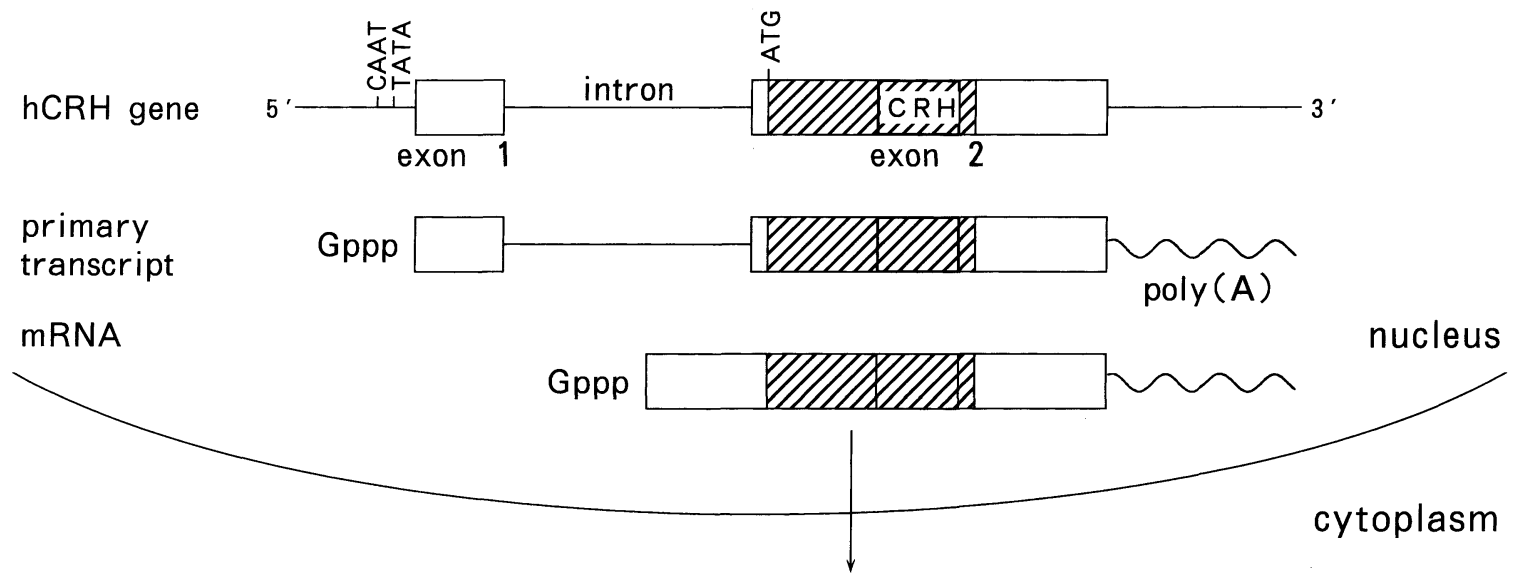

mRNA

preproCRH

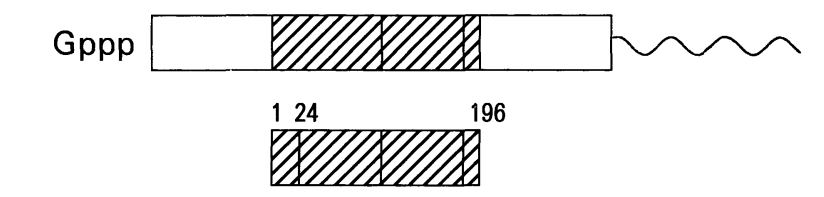

signal peptide

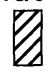

$\mathrm{CRH}$

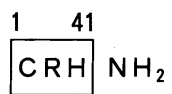

Fig. 1. Process of CRH gene expression and peptide synthesis. The $\mathrm{CRH}$ gene contains two exons and one intron. The coding region of the CRH precursor is present in exon 2. DNA and RNA regions encoding CRH precursor, as well as CRH precursor peptide are depicted as shaded areas. The prepro-CRH consists of 196 amino acid residues, with the sequence of 24 amino-terminal residues exhibiting the characteristic features of a signal peptide associated with secretory proteins. The CRH precursor is cleaved in the secretory granule, and the 41 amino acid peptide $\mathrm{CRH}$ is produced. The carboxy-terminal isoleucine residue of human $\mathrm{CRH}$ is then amidated.

regulatory elements in the 5 '-flanking DNA sequence of the CRH gene (for review, see [16]). It remains to be fully understood, however, whether these elements are functionally involved in transcriptional regulation of the gene (see below). The primary transcript of the $\mathrm{CRH}$ gene (heteronuclear RNA, or hnRNA) is enzymatically spliced to become mature mRNA. The mature mRNA is transported to the cytoplasm where it is translated to the precursor of CRH (prepro-CRH).

The prepro-CRH consists of 196 amino acid residues [8], with the sequence of 24 amino-terminal residues exhibiting the characteristic features of a signal peptide associated with secretory proteins [8]. The CRH precursor is cleaved in the secretory granule, and the 41 amino acid peptide CRH is produced. The carboxy-terminal isoleucine residue of human CRH (hCRH) is then amidated.

In the rat hypothalamus, $\mathrm{CRH}$ immunoreactive cells are localized primarily in the medial parvocellular division of the PVN and periventricular nucleus [2, 4]. Magnocellular oxytocinergic neurons in the PVN and supraoptic nucleus (SON) contain less prominent $\mathrm{CRH}$ immunoreactivity [17]. In humans, $\mathrm{CRH}$ immunoreactivity was also demonstrated in the parvocellular neurons in the PVN $[18,19]$, with no detectable immunoreactivity in magnocellular cells in the PVN or SON $[18,20]$.

The distribution of CRH containing cells in the brain has been extensively studied in the rat. $\mathrm{CRH}$ immunoreactivity and mRNA expression were identified in extrahypothalamic regions, including inferior olivary nucleus, central nucleus of the amygdala, Barrington's nucleus in the pons, cerebellum, and the cerebral cortex [21-27].

In the adult mouse brain, the highest levels of CRH mRNA were observed in the PVN and the 


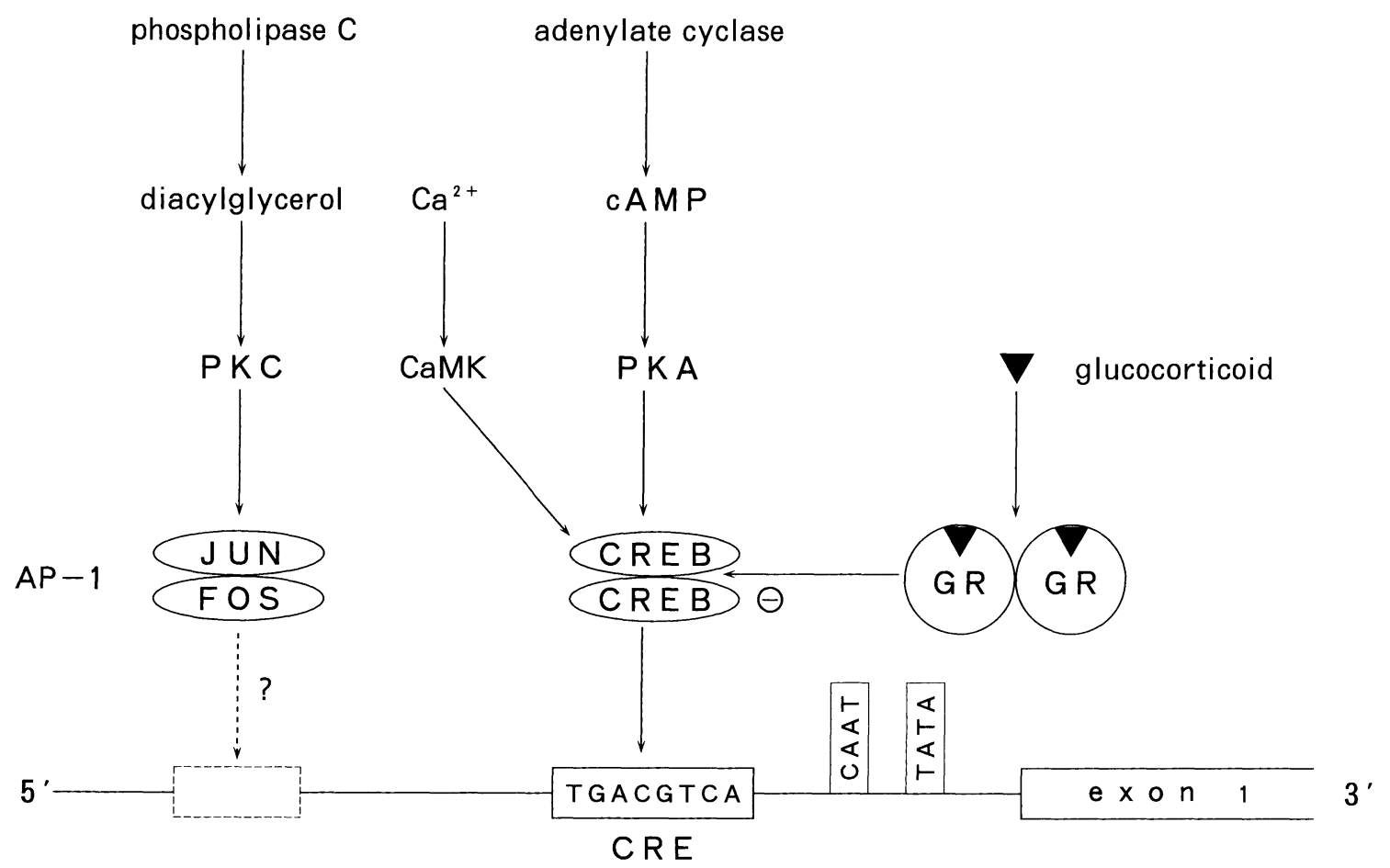

Fig. 2. Postulated intracellular regulatory mechanisms of $\mathrm{CRH}$ gene transcription. The functionality of the CRE, $5^{\prime}-$ flanking the CRH gene, is well established in cell culture system transfected with CRH promoter-reporter construct. The cAMP-dependent PKA pathway may play an essential role in CRH gene expression. The role of the PKC pathway is still controversial. Interaction, whether direct or indirect, between GR and CREB proteins has been proposed to be the mechanism of glucocorticoid repression. PKC, protein kinase C; PKA, protein kinase $\mathrm{A}$; cAMP , 5' 3' $^{\prime}$-cyclic adenosine monophosphate; $\mathrm{CaMK}, \mathrm{Ca}^{2+} /$ calmodulin-dependent protein kinase; CRE, cAMP response element; CREB, CRE-binding protein; GR, glucocorticoid receptor; AP-1, activator protein-1.

inferior olivary nuclei by in situ hybridization [28]. Barrington's nucleus also showed dense hybridization signals. Expression in the PVN was present mainly in the parvocellular neurons, with some scattered low level expression in magnocellular neurons [28]. Several hypothalamic nuclei, including the lateral hypothalamus, dorsomedial hypothalamus, perifornical zone, preoptic areas, as well as the bed nucleus of the stria terminalis (BNST) also expressed CRH mRNA [28].

\section{Cyclic AMP (cAMP)-dependent protein kinase $A$ (PKA) pathway}

The cyclic AMP-dependent PKA pathway has been implicated in the regulation of CRH synthesis and/or secretion. Suda et al. [29] have reported that cAMP increases CRH release from the rat hypothalamus in vitro. Emanuel et al. have shown that forskolin, an activator of adenylate cyclase, increases CRH secretion and CRH mRNA levels in cultured rat fetal hypothalamus [30].

The 5 '-flanking regions of the mammalian CRH genes contain the consensus cAMP response element (CRE) sequence (5'-TGACGTCA-3'), and this CRE has been shown to be functional (Fig. 2); chloramphenicol acetyltransferase (CAT) expression was activated by cAMP analogs and activators of adenylate cyclase in tumor cell lines transfected with rat or human CRH promoters fused to the CAT gene [31, 32]. The cAMP-activated expression was profoundly diminished by either deletion of the $5^{\prime}$-flanking regions containing the CRE sequence $[31,32]$ or by mutation of CRE sequence into an AP-1 site (TGAGTCA) [32]. These results were observed in rat pheochromocytoma PC-12 [31], human neuroblastoma SK-N-MC, and human choriocarcinoma JAR cell lines [32]. CAT expression was not induced by cAMP, however, 
in a mouse teratocarcinoma cell line, F9, which possesses low levels of endogenous CRE-binding proteins (CREB) [32], indicating that the CREB protein is required for this cAMP-dependent activation. Imura's [33] and Holsboer's groups [34] also showed activation of the hCRH gene by cAMP in a mouse corticotroph AtT-20 cell line transfected with an intact genomic fragment including $5^{\prime}$ flanking region of the hCRH gene or a hCRH-reporter construct, respectively.

Seasholtz's group [35] has shown that potassiuminduced membrane depolarization increased expression of a CRH-reporter construct transfected into PC-12 cells in a cAMP dependent manner. This synergistic activation was mediated via calcium influx and calmodulin. Since the nuclear protein profile as determined by DNase protection assay across the CRE appears unchanged after incubation with extracts derived from PC-12 cells treated with forskolin, potassium, or potassium/forskolin, CREB or a similar protein from the CREB/ATF family may bind under these conditions [35]. Thus, the nuclear proteins binding to the CRE may integrate signals initiated by cAMP and calcium pathways. The mechanism of this synergy remains to be clarified.

Itoi and colleagues [36] reported that 8-Br-cAMP directly injected into the PVN of conscious rats increased CRH mRNA levels in the hypothalamus in vivo, suggesting the physiological significance of the cAMP-dependent PKA pathway in the regulation of $\mathrm{CRH}$ gene. They showed further that treatment with antisense oligodeoxyribonuleotide against CREB attenuated the stress-induced CRH gene expression, suggesting the involvement of CREB protein in mediating stress-signals to the $\mathrm{CRH}$ gene [36]. Kovacs and Sawchenko [37] also reported rapid phosphorylation of CREB after ether stress, with a time course parallel to that of CRH hnRNA levels, consistent with the view that the PKA pathway is important in transducing stressinduced signals to the CRH gene.

\section{Diacylglycerol-dependent protein kinase C pathway}

Although multiple potential TPA response elements (TREs) are present in the $5^{\prime}$-flanking region of the CRH gene [38], it is still controversial whether the TRE is functionally involved in transcriptional regulation of the $\mathrm{CRH}$ gene. A phorbol ester, 12-O-tetradecanoyl phorbol 13acetate (TPA), has been reported to stimulate $\mathrm{CRH}$ gene expression as well as CRH secretion in primary cultures of fetal rat hypothalamic cells [30]. Vamvakopoulos and Chrousos reported positive regulation of the $\mathrm{CRH}$ gene by TPA using a hCRH promoter-CAT construct transfected into the COS7 cells, although they did not identify the promoter sequence responsible for the gene activation [39]. Rosen and colleagues showed up-regulation of CRH mRNA levels by TPA in NPLC human hepatoma cell line [40]. By contrast, no transcriptional activation of $\mathrm{CRH}$ promoter-CAT constructs was detected after treatment with phorbol esters in PC12 or AtT20 cells (Seasholtz, unpublished data and [34] for AtT20). It is possible, therefore, that the action of TPA on CRH gene transcription may be highly cell-type specific. It should be kept in mind that the intracellular milieu in transfected cell lines may be quite different from that in CRH neurons, and the results obtained in cell lines may not necessarily be extrapolated to the response in CRH neurons. TPA has also been shown to increase CRH mRNA poly-A tail length in the human hepatoma cell line, NPLC, which may influence CRH mRNA stability or translatability, and may explain the mechanism of the reported increase in CRH gene expression by the PKC pathway [41].

Both c-fos mRNA and c-jun mRNA increased in the hypothalamus following insulin-induced hypoglycemia [36], known as a potent stimulus for $\mathrm{CRH}$ gene expression [42]. However, microinjection of TPA into the PVN of conscious rats failed to influence hypothalamic CRH mRNA levels [36]. Treatment with antisense oligodeoxyribonucleotide directed against c-fos or c-jun did not attenuate the stress-induced up-regulation of hypothalamic CRH mRNA level [36]. These results at least suggest that the involvement of PKC and/or AP-1 appears to be less important, with respect to the stressstimulated $\mathrm{CRH}$ gene transcription. At present, the physiological significance of the immediate early response of c-fos and c-jun mRNA in the hypothalamus following stress is unclear. Initiation of $\mathrm{CRH}$ gene transcription, as determined by levels of CRH heteronuclear RNA, has been reported to occur as early as c-fos mRNA, also suggesting that the early response of $c-f o s$ mRNA has a correlative, 
but not causal relationship, with $\mathrm{CRH}$ gene expression [43].

\section{Glucocorticoid negative feedback}

$\mathrm{CRH}$ immunoreactivity in the PVN as well as in the external layer of the median eminence was markedly increased following bilateral adrenalectomy (ADX) [44-46]. The increase in CRH immunoreactivity was suppressed by treatment with glucocorticoid [46]. Likewise, CRH mRNA level was elevated by ADX, and suppressed by systemic dexamethasone [47] or corticosterone administration [48]. Suppression of CRH mRNA by glucocorticoids was specific for the PVN, with no detectable change in the central amygdaloid nucleus (CeA), BNST or supraoptic nucleus (SON) as determined by Northern blot [49]. In contrast, Swanson and Simmons [48] reported up-regulation of CRH mRNA in the CeA and SON as well as in some parvocellular divisions (dorsal and ventral medial parts) of the PVN after corticosterone replacement. Plotsky and Sawchenko [50] showed increased hypophysial-portal plasma levels of CRH following pharmacological adrenalectomy with metyrapone and aminoglutethimide. Postadrenalectomy up-regulation of $\mathrm{CRH}$ immunoreactivity and mRNA expression were both normalized following implants of steroid pellets into the PVN, suggesting the local action of glucocorticoid on CRH neurons [51-53]. These results clearly demonstrate that glucocorticoids negatively regulate CRH expression in the PVN.

The molecular events involved in the negative glucocorticoid regulation of $\mathrm{CRH}$ gene expression have been explored. Majzoub's group showed that dexamethasone treatment for $24-96 \mathrm{~h}$ caused a decrease in CRH mRNA levels by $40-50 \%$ [54] and repressed forskolin-stimulated $\mathrm{CRH}$ mRNA expression by $70-80 \%$ [40] using transfected AtT20 cells with an 8-kb DNA fragment containing the hCRH gene, including $5 \mathrm{~kb} 5^{\prime}$-flanking and 1 $\mathrm{kb}$ 3'-flanking DNA. Dexamethasone reduced CAT activity in AtT-20 cells transiently transfected with hCRH promoter-CAT construct [34]. These data indicate that the promoter region of the $\mathrm{CRH}$ gene is responsible for negative glucocorticoid regulation.

The mechanism of positive transcriptional regulation by glucocorticoid has been studied extensively. The glucocorticoid receptor (GR) is regarded as the prototype of ligand-activated transcription factors. Negative glucocorticoid regulation, however, has been identified in only a small number of genes including POMC [55-57], collagenase [58], $\alpha$-glycoprotein hormone [59, 60], prolactin [61, 62], proliferin [63], and osteocalcin [64]. Although GR is required for the negative glucocorticoid regulation of all these genes, its interactions with specific DNA-regulatory sequences and with other transcription factors seem to be highly specific to the promoter and cell type. Recently, Seasholtz's group [65] has explored the molecular mechanisms mediating the glucocorticoid repression of cAMP-induced $\mathrm{CRH}$-reporter expression in AtT-20 cells. They showed that deletion and/or mutation of any potential GRbinding sites, identified by DNase I protection assays, failed to block the negative glucocorticoid regulation, implying that mechanisms other than direct binding of GRs to DNA may be important for the negative glucocorticoid regulation of the $\mathrm{CRH}$ gene [65]. Furthermore, an 18-bp DNA fragment containing the CREB was sufficient to confer both positive cAMP regulation and glucocorticoid repression of cAMP-activated CAT activity to a heterologous promoter [65]. These results suggest that some interactions, whether direct or indirect, between GR and CREB proteins may be the mechanism of glucocorticoid repression of CRH gene expression in AtT20 cells (Fig. 2). It should also be noted, however, that a recent study by Dorin and colleagues suggests that the putative GR binding site at -278 to $-249 \mathrm{bp}$ may be important for negative glucocorticoid regulation when additional GR is expressed in transfected AtT20 cells [66].

\section{CRH gene expression during ontogeny of $C R H$ neurons}

During embryonic and perinatal development of the PVN, CRH gene expression showed a characteristic profile both in rats and mice. CRH mRNA was recognized on embryonic day 17 (e17) adjacent to the third ventricle of the rat brain by in situ hybridization despite the fact that the PVN could not be identified morphologically [67]. Presence of CRH immunoreactivity in the PVN [68] or median eminence [69] was reported on e15.5- 
16.5 and e18, respectively. CRH mRNA levels increased until e20, but on e21, the density decreased markedly, and reached its nadir on postnatal day 1 (p1). After birth, CRH mRNA levels increased again until $\mathrm{p} 7$, then did not increase further. In contrast to the perinatal decrease in mRNA, hypothalamic CRH peptide showed a steady increase during development [70]. This may be explained by a decrease in peptide release during the perinatal period.

In the mouse, $\mathrm{CRH}$ mRNA was first observed on e13.5 in the PVN, Barrington's nucleus, olivary complex, and amygdaloid primordia. CRH mRNA was not detectable in the cortex until after birth [28]. In the PVN, CRH mRNA increased until e17.5. From e17.5 through p1, there was a 2.8-fold drop in mRNA levels. By p3, CRH mRNA levels started to increase, and by p14, expression was similar to that in the adult [28].

It is known that the neonatal rat exhibits a reduced capacity to secrete $\mathrm{ACTH}$ and corticosterone in response to certain stressors [71], often termed the "stress nonresponsive period" (SNRP). Decreased mRNA levels during this time suggest the decreased synthesis of $\mathrm{CRH}$. It should be noted that POMC mRNA levels in the neurointermediate lobe, which is devoid of glucocorticoid receptors, increased steadily, despite the marked decrease in hypothalamic CRH mRNA and POMC mRNA levels in the anterior pituitary [67]. This raises the possibility that increased glucocorticoid negative feedback may underlie this phenomenon [72]. The biological significance of the SNRP remains to be explained.

DNA sequences which determine tissue-specific expression of the CRH gene have been explored using transgenic mice, and very large regions of 5'- and/or 3'-flanking DNA sequences appear to be important for cell-specific expression and developmental regulation of CRH gene [73]. Cellspecific expression improved significantly with the inclusion of $8.7 \mathrm{~kb}$ of CRH $5^{\prime}$-flanking DNA, the entire CRH structural gene, and $2 \mathrm{~kb}$ of $\mathrm{CRH} 3^{\prime}-$ flanking DNA [73]. However, even with the inclusion of $21 \mathrm{~kb}$ of 5 'flanking CRH DNA, the $\mathrm{CRH}$ transgene was not properly expressed compared to the endogenous CRH gene [74].

\section{Extracellular Regulatory Mechanisms of CRH Neurons}

As described in the previous section, glucocorticoids are the most important humoral factors in the regulation of $\mathrm{CRH}$ neurons. In this section we will focus on the roles of neural inputs to the $\mathrm{CRH}$ neurons and another important humoral factor, interleukin-1.

\section{Brain stem catecholaminergic neurons}

Among the neurotransmitter systems involved in the regulation of hypothalamic CRH neurons the catecholaminergic neuronal systems have been studied most extensively. Plotsky and colleagues [75] have reviewed this subject comprehensively. In the present review, we will further discuss recent advances in this subject. The parvocellular division of the PVN receives large inputs from the norepinephrine (NE)- or epinephrine (E)-containing neurons in the lower brain stem [76-80]. Liposits and colleagues [81] have reported, using electron microscopic immunocytochemistry, that tyrosine hydroxylase-immunoreactive nerve terminals make direct synaptic contact with CRH neurons in the PVN. Furthermore, a substantial number of $\mathrm{CRH}$ neurons are in juxtaposition with dopamine- $\beta$ hydroxylase-containing axon terminals. These anatomical findings strongly suggest that catecholamines play a transmitter role in the PVN and that catecholaminergic inputs modulate the synthesis and/or secretion of CRH. The medial parvocellular division of the PVN, the main source of the tuberoinfundibular CRH fibers, is innervated by the $A_{2}$-noradrenergic [79] and $C_{1^{-}}, C_{2^{-}}$, and $C_{3^{-}}$ adrenergic cell groups [80] in the medulla oblongata. Whereas the $A_{6}$-noradrenergic groups innervate mainly the periventricular nucleus, $\mathrm{A}_{1^{-}}$ noradrenergic group innervates the magnocellular division of the PVN and the SON [79].

Earlier work by Ganong and colleagues [82] suggested an inhibitory role of hypothalamic NE in the HPA-axis regulation. However, more recent pharmacological in vivo evidence, using conscious rats and sheep, unequivocally support the idea that NE stimulates CRH neurons in the PVN, thus positively regulating the HPA-axis [83-86]. Plotsky [87] reported, by measuring $\mathrm{CRH}$ concentrations 
in hypophysial portal blood in urethaneanesthetized rats, that NE, injected intracerebroventricularly (icv), stimulates $\mathrm{CRH}$ secretion at lower doses; however, it inhibits $\mathrm{CRH}$ secretion at higher doses. Although the reason for the discrepancies between these studies are not clear, it should be kept in mind that anesthetics are, in themselves, potent modulators of neurons in the central nervous system, and pharmacological agents may elicit different, or even completely opposite, reactions depending on the anesthetic and the doses used. Recently, Itoi and colleagues [85] reported that $\mathrm{NE}$, microinjected into the PVN of conscious rats, stimulated CRH mRNA expression in the hypothalamus as seen by Northern blot analysis. Furthermore, the stimulatory action of $\mathrm{NE}$ on CRH gene expression was proved to be at the transcriptional level by quantitative in situ hybridization using an intronic riboprobe (Itoi $e t$ al., unpublished observations).

The results of in vitro experiments, in which cultured hypothalamic cells [88] or the hypothalamic organ culture are used, are equivocal [89-93]. These data should be interpreted with caution, since isolated $\mathrm{CRH}$ neurons and the dissected hypothalamus may respond differently from the way they would in the physiological state. $\mathrm{CRH}$ neurons are innervated by numerous afferents from other brain regions as well as intrahypothalamic interneurons [94], and the basal tones of these afferents may determine the responsiveness of $\mathrm{CRH}$ neurons to any specific stimulus.

Lesions of the ventral noradrenergic bundle (VNAB) by 6-hydroxydopamine (6-OHDA) diminished CRH immunoreactivity in the PVN and median eminence [95] as well as HPA response to ether stress [96]. NE release in the PVN may depend mainly on ascending medullary tracts from ipsilateral brain stem noradrenergic cell groups since catecholamine-depleting medullary knife cuts attenuated the number of CRH immunoreactive cells on the side ipsilateral to the cut [97]. NE release after immobilization stress, assessed by brain microdialysis [98], was reduced on the ipsilateral side of the brain stem hemisection [99]. Moreover, CRH levels in the hypophysial portal blood were reduced after a 6-OHDA lesion of the VNAB [100]. These results further support the hypothesis that the ascending noradrenergic system stimulates $\mathrm{CRH}$ neurons in the PVN, although Harbuz and colleagues [101] have reported results contradictory to this hypothesis.

Pharmacological actions of epinephrine (E) on hypothalamic $\mathrm{CRH}$ neurons have been less extensively studied compared to $\mathrm{NE}$, and the regulatory role of $\mathrm{E}$ in the HPA-axis is still controversial [102-104].

Many lines of evidence obtained in in vivo experiments support the view that the $\alpha_{1}$-adrenergic receptors mediate catecholaminergic transmission to hypothalamic CRH neurons [85, 87, 105, 106]. In vitro results are, again, controversial, suggesting an involvement of $\alpha_{1^{-}}, \alpha_{2^{-}}$[93], or $\beta$-adrenoceptors [92]. By autoradiographic localization of ligand binding, $\alpha_{1^{-}}, \alpha_{2^{-}}$, and $\beta$-receptors all have been shown to be present in the PVN [107-110].

The ascending catecholaminergic system has been proposed to be activated when animals are exposed to various kinds of stress such as restraint, inhalation of ether, histamine and insulin-induced hypoglycemia [111] or interleukin-1 challenge (see below).

\section{Cholinergic system}

Acetylcholine (ACh) has been proposed to stimulate $\mathrm{CRH}$ neurons in the PVN. This hypothesis is based on pharmacological evidence obtained in vitro and in vivo. ACh has been found to stimulate $\mathrm{CRH}$ release from isolated rat hypothalamus [112-115] and cultured hypothalamic cells [116]. Implantation of atropine, a muscarinic cholinergic receptor antagonist, into the hypothalamus inhibits corticotropin release [117]. Intravenous (iv) injection of cholinergic agonist, arecoline, stimulated ACTH secretion through a centrally mediated CRH-dependent mechanism [118]. Recently, Ohmori and colleagues [119] showed that ACh, microinjected into the PVN of conscious rats, stimulated CRH gene expression. Surprisingly, ACh was three orders of magnitude more potent than NE in stimulating $\mathrm{CRH}$ gene expression [119].

The presence of both nicotinic [120] and muscarinic [121-123] receptors has been reported in the PVN by autoradiography using specific radioligands. Although the specificity of the ligand used to detect nicotinic receptors in the classical binding studies was challenged later, more recent 
immunocytochemical and in situ hybridization studies have confirmed the presence of both nicotinic [124, 125] and muscarinic [126, 127] receptors in the hypothalamus. The ACh-induced ACTH secretion was inhibited by a muscarinic antagonist, atropine, but not by a nicotinic antagonist, hexamethonium, in conscious rats, suggesting the involvement of muscarinic receptors [119]. In isolated hypothalami, however, both muscarinic and nicotinic antagonists were reported to inhibit the action of ACh [112, 114, 115].

Choline acetyltransferase-immunoreactive nerve terminals are distributed in hypothalamic areas that surround the PVN, e.g., zona incerta (dorsally), perifornical nucleus (ventrolaterally), and dorsal hypothalamic nuclei (ventrally), but few or no punctate varicosities have been labeled within the PVN at the light microscopic level [128]. Therefore, the cholinergic influence on CRH neurons may be indirect via interneurons or involve synapses on dendrites of $\mathrm{CRH}$ neurons outside the PVN. The origin of cholinergic neurons innervating the areas adjacent to the PVN is not yet clear. Ablation of the lateral septum was found to decrease choline acetyltransferase concentrations in the PVN and adjacent structures, suggesting a septal origin of cholinergic innervation of these areas [129]. This raises the possibility that cholinergic regulation of hypothalamic CRH neurons may be related to the septohypothalamic integration of the emotional, neuroendocrine, and behavioral states of animals. There is another conspicuous zone of cholinergic neurons in the lateral tegmental area of the rostral rhombencephalon which projects to the hypothalamus [130-132]. This zone includes the pedunclopontine and laterodorsal tegmental nuclei [130-132]. The former, also called the parabrachial nucleus [131], sends direct input to hypothalamic nuclei including the PVN [132]. Cholinergic fibers originating from the pedunculopontine tegmental nucleus have been traced to the zona incerta and lateral hypothalamic area [133], which are located in the proximity of the PVN. This anatomical evidence raises the possibility that the pontine nuclei are involved in activation of $\mathrm{CRH}$ neurons in the PVN via the cholinergic mechanism. The pontine nuclei belong to the ascending reticular activating system, which is involved in the alertness of animals. Further studies are required to elucidate the physiological implications of the cholinergic system in regulating the HPA-axis.

\section{Serotoninergic system}

The PVN region is densely innervated by serotoninergic fibers. The highest density was observed in areas surrounding the PVN, but the PVN itself, including the parvocellular divisions, also contained 5-hydroxytryptamine (5-HT) varicosities [134]. These serotoninergic neurons could be traced to the $B_{7}, B_{8}, B_{9}$ cell groups in the midbrain [134]. Liposits and colleagues showed, using electron microscopic immunocytochemistry, that the serotonin-containing terminals formed axodendritic and axo-somatic synapses with CRH-immunoreactive neurons in the PVN [135]. These anatomical data suggest direct serotoninergic regulation of hypothalamic CRH neurons.

Electrical stimulation of the dorsal raphe nucleus, where serotoninergic neurons originate from, elicited excitation of the majority of the hypothalamic cells which was blocked by a serotonin depleting drug, parachlorophenylalanine [136]. Pharmacological studies have shown that 5HT stimulates secretion of CRH in vitro $[89,114$, 137]. A serotonin reuptake inhibitor, fluoxetine, increased CRH concentration in hypophysial portal blood [138]. These results all favor the hypothesis that the serotoninergic system regulates hypothalamic CRH neurons positively. Injection of 8-OH-DPAT, a $5-\mathrm{HT}_{1 \mathrm{~A}}$ receptor agonist, into the PVN resulted in corticosterone secretion dosedependently [139], suggesting an involvement of $5-\mathrm{HT}_{1 \mathrm{~A}}$ receptor in serotoninergic transmission at the $\mathrm{CRH}$ neurons.

\section{Histaminergic system}

The hypothalamus contains the highest density of histamine (HA)-containing fibers, as identified by immunohistochemistry using an antihistidine decarboxylase antibody [140]. Both the parvocellular and magnocellular divisions of the PVN are innervated by histaminergic neurons. The cells of origin of these fibers remain to be clarified.

HA has been proposed to be a positive regulator of CRH neurons. The icv injection of HA increased plasma ACTH, which was prevented by pretreatment with anti-CRH antiserum, suggesting an action of HA on CRH secretion [141]. Insulin- 
induced hypoglycemia, a potent stimulus for CRH synthesis and secretion [42, 142], may be mediated by the histaminergic system [143] since pretreatment with an HA synthesis inhibitor, $\alpha$ fluoromethylhistidine, inhibited the ACTH response to insulin-induced hypoglycemia. Furthermore, HA-induced ACTH secretion was inhibited by $\mathrm{H}_{1}$-antagonists, mepyramine and cetirizine, and to a lesser extent by $\mathrm{H}_{2}$-antagonists, cimetidine and ranitidine, suggesting the involvement of both $\mathrm{H}_{1-}$ and $\mathrm{H}_{2}$-receptors [143]. ICV injection of $\mathrm{HA}$ also induced c-fos expression in CRH-containing neurons, as well as in vasopressin- or oxytocin-containing neurons in the PVN and SON [144].

\section{Gamma-amino butyric acid (GABA)-containing system}

The hypothalamus is densely innervated by GABA-containing nerve terminals, identified by immunocytochemistry using antibodies against glutamate decarboxylase, the GABA synthetic enzyme. According to Decavel and Van Den Pal [145], GABA immunoreactive terminals account for about half of the total synaptic input to the major hypothalamic nuclei, including the PVN, SON, the arcuate nucleus, and suprachiasmatic nucleus. It is not clear whether these GABAergic neurons are hypothalamic interneurons or afferents of the projecting neurons from other brain areas.

GABA is a major inhibitory neurotransmitter in the central nervous system and also presumed to negatively regulate the CRH neurons in the PVN. There is pharmacological evidence showing unequivocally that GABA functions as an inhibitory transmitter in the hypothalamic network regulating $\mathrm{CRH}$ secretion both in vitro $[89,146]$ and in vivo $[147,148]$. GABA inhibited acetylcholine-induced $\mathrm{CRH}$ release which was prevented by the GABA antagonist bicucullin [89]. Calogero and colleagues [146] showed that both muscimol, a $\mathrm{GABA}_{\mathrm{A}}$ receptor agonist, and baclofen, a $G A B A_{B}$ receptor agonist, inhibited 5-HT-induced CRH release from isolated rat hypothalamic tissue, suggesting the involvement of both $\mathrm{GABA}_{A}$ and $\mathrm{GABA}_{B}$ receptors in the GABA transmission.

Makara and Stark [147] have shown that icv GABA inhibits stress-induced ACTH release, and GABA antagonists, picrotoxin and bicucullin, stimulate ACTH release. Recently, Stotz-Potter and colleagues [148] have shown that bilateral microinjection of muscimol into the PVN reduces the magnitude of acute stress-induced plasma ACTH increase.

Hippocampal formation has been proposed to mediate glucocorticoid negative feedback via its efferents to the PVN (see below). There are no significant direct projections from the hippocampus to the PVN [149, 150]; hippocampal efferents are thought to involve at least one intervening synapse on their way to the PVN. Cullinan and colleagues have shown that the axons originating from the ventral subiculum innervate PVN-projecting cells located within the BNST [151]. Moreover, a proportion of PVN-projecting cells in the BNST are GABAergic, suggesting that hippocampal regulation of hypothalamic CRH neurons may be mediated by the GABAergic input from the BNST [151].

\section{Interleukin-1}

Interleukin-1 (IL-1) belongs to a group of cytokines produced during infectious and inflammatory processes. IL-1, administered either centrally or peripherally, has been shown to activate the HPA-axis. It is still controversial whether IL-1 acts at the pituitary level [152-155]. A stimulatory effect of IL-1 on the synthesis and secretion of adrenocortical steroid has been reported [156, 157]. There has been a substantial body of evidence that IL-1 acts primarily through a central mechanism. For example, intravenous infusion of IL-1 stimulated the release of hypothalamic $\mathrm{CRH}$, which was measured in pituitary portal blood [153]. Furthermore, an injection of anti-CRH antibodies, prior to administration of IL-1 abolished the IL-1induced increase in ACTH [153, 158]. IL-1 injected intraperitoneally increased hypothalamic $\mathrm{CRH}$ mRNA levels [155]. Electrolytic destruction of the PVN completely blocked the IL-1-induced increase in plasma ACTH [159].

Since IL-1 is a $17-\mathrm{kDa}$ protein, and may not readily be able to pass through the blood-brain barrier, it has been a matter of dispute how circulating IL-1 gains access to the brain parenchyma to exert its effects. Circumventricular organs such as the organum vasculosum of lamina terminalis (OVLT), which lack a functional barrier, 
are hypothesized to be a venue for conveying IL1-mediated signals to CRH neurons in the PVN [160]. However, IL-1 receptor mRNA was not observed in the OVLT [161], and therefore, this hypothesis needs to be reevaluated (see below).

Central catecholaminergic neurons have been proposed to be involved in IL-1-induced stimulation of CRH neurons in the PVN. For example, 6-OHDA lesioning of either the ventral noradrenergic bundle [162, 163] or the PVN [163] reduced IL-1-induced activation of the HPA-axis. Unilateral transections of the ascending catecholaminergic projections from the medulla attenuated IL-1-stimulated increases in Fos immunoreactivity and CRH mRNA in the PVN on the ipsilateral side [164]. Vagal and glossopharyngeal afferents have been proposed to transmit the interoceptive signals, primarily produced by IL- 1 in the periphery, to the nucleus of the solitary tract (NTS), from which the ascending catecholaminergic fibers originate [164].

Distribution of IL-1 receptors is reported in mouse [165, 166] and rat brain [161] by either ligand-binding [166] or in situ hybridization [161, 166]. IL-1 receptor is most prominently expressed in non-neural structures including the blood vessels and choroid plexus in both mice and rats, suggesting that these non-neuronal cells may be the primary sites of action of IL-1 in the brain. The area postrema, among the circumventricular organs, is the only reported site which bears IL-1 receptor mRNAs [161]. There is a neural input from the area postrema to the NTS, from which the catecholaminergic fibers may mediate transmission to the PVN. Further studies are required to elucidate the site of action of circulating IL-1 and the neural pathways which transmit IL-1induced signals to the hypothalamic $\mathrm{CRH}$ neurons.

\section{Other possible transmitters/modulators and neural pathways}

Putative neurotransmitters or modulators proposed to regulate $\mathrm{CRH}$ neurons in the PVN,

Table 1. Neurotransmitters/modulators and humoral factors postulated to regulate tuberoinfundibular CRH neurons

\begin{tabular}{|c|c|c|c|c|}
\hline & cells of origin & secretion & synthesis & references \\
\hline \multicolumn{5}{|c|}{ transmitter/modulator } \\
\hline norepinephrine & $A_{2}$ & $\uparrow$ & $\uparrow$ & $76-79,81-93,95-101$ \\
\hline epinephrine & $\mathrm{C}_{1}, \mathrm{C}_{2}, \mathrm{C}_{3}$ & $\uparrow$ & $(\downarrow)$ & $80,102-104$ \\
\hline acetylcholine & septum? LDTg? PPN? & $\uparrow$ & $\uparrow$ & $112-119,128-133$ \\
\hline serotonin & raphe nuclei & $\uparrow$ & & $89,114,134-139$ \\
\hline histamine & & $\uparrow$ & & $140,141,143,144$ \\
\hline GABA & BNST & $\downarrow$ & & $89,145-148,151$ \\
\hline neuropeptide $Y$ & arcuate nucleus, $A_{1}, C_{1}, C_{2}, C_{3}$ & $\uparrow$ & $\uparrow$ & $167-170$ \\
\hline angiotensin II & subfornical organ & $\uparrow$ & $\uparrow$ & $29,171,173-177$ \\
\hline$\beta$-endorphin & arcuate nucleus & $\downarrow(\uparrow)$ & $\downarrow$ & $178-182$ \\
\hline dynorphin & & $\downarrow$ & & 181 \\
\hline cholecystokinin & & $\uparrow$ & & 183,184 \\
\hline substance $P$ & $\begin{array}{l}\text { hypothalamus, } \mathrm{LDTg}, \mathrm{PPN} \\
\text { ventrolateral medulla }\end{array}$ & $\downarrow$ & & 185,186 \\
\hline enkephalin & NTS & $\uparrow$ & & $187,188,195$ \\
\hline somatostatin & NTS & $\downarrow$ & & $189,190,195$ \\
\hline galanin & $\mathrm{A}_{1}, \mathrm{~A}_{6}, \mathrm{DMH}$ & $\downarrow$ & & $169,191,192$ \\
\hline activin & NTS & $\uparrow$ & & 193-195 \\
\hline \multicolumn{5}{|l|}{ humoral factor } \\
\hline glucocorticoid & adrenal cortex & $\downarrow$ & $\downarrow$ & $44-53$ \\
\hline interleukin-1 & macrophage, monocyte & $\uparrow$ & $\uparrow$ & $153,155,158-164$ \\
\hline
\end{tabular}

$A_{1,2,6}$, norepinephrine-containing cells; $C_{1-3}$, epinephrine-containing cells; LDTg, laterodorsal tegmental nucleus; PPN, pedunculopontine nucleus; BNST, bed nucleus of the stria terminalis; NTS, nucleus of the solitary tract; $\mathrm{DMH}$, dorsomedial hypothalamus. $\uparrow$ and $\downarrow$ indicate stimulatory and inhibitory effects, respectively. In parentheses if not uniformly observed or unequivocally accepted. 
including those discussed above, are listed in Table 1.

Neuropeptide $Y$ (NPY) is contained in catecholaminergic $C_{1}, C_{2}, C_{3}$, and $A_{1}$ neurons [167] as well as neurons in the arcuate nucleus [168] which project to the PVN. NPY-containing nerve terminals make direct synaptic contact with both parvo- and magnocellular neurons in the PVN [169]. NPY [170] injected icv stimulated hypothalamic CRH mRNA levels. Implications of colocalization of NPY with catecholamines remain to be studied.

Angiotensin II (AII) containing neurons originating from the subfornical organ (SFO) innervate the PVN [171]. The SFO is one of the circumventricular organs which has been implicated in the control of vasopressin (AVP) release from the neurohypophysis and the maintenance of body fluid homeostasis [172]. Besides neurohypophysial-projecting oxytocin or AVP cells, tuberoinfundibular neurons, most likely containing $\mathrm{CRH}$ or thyrotropin-releasing hormone, were orthodromically activated by electrical stimulation of the SFO [173]. SFO also bears AII receptors [174], and its activity may be influenced by circulating AII levels [175]. AII stimulates CRH release both in vitro [29] and in vivo [176]. Moreover, AII was demonstrated to increase CRH mRNA levels in the hypothalamus by Northern blot analysis [176] and in situ hybridization [177], suggesting their positive regulatory roles in CRH gene expression. Expression of type $1 \mathrm{AII}$ receptor $\left(\mathrm{AT}_{1}\right) \mathrm{mRNA}$ and $\mathrm{AT}_{1}$ receptor binding, determined by ${ }^{125} \mathrm{I}\left[\mathrm{Sar}^{1}, \mathrm{Ile}^{8}\right] \mathrm{AII}$, were localized to the periventricular and parvocellular divisions of the PVN [177]. Physiological significance of the AII system in CRH neuron regulation needs to be clarified.

$\beta$-endorphin is contained in the arcuate nucleus neurons along with other POMC peptides which project directly to the PVN $[178,179]$. $\beta$-endorphin inhibits stress-induced up-regulation of CRH mRNA levels, suggesting its suppressive effect on CRH gene expression [180]. Following icv injection of $\beta$-endorphin or dynorphin CRH release into the hypophysial-portal circulation was decreased [181]. Bimodal effect of $\beta$-endorphin on CRH release was reported in isolated rat hypothalami [182].

Other transmitter/modulator candidates for CRH neuronal regulation are cholecystokinin [183, 184], substance $P[185,186]$, enkephalins [187, 188], somatostatin [189, 190], galanin [169, 191, 192], and activin [193,194]. A considerable portion of inhibin $\beta$-containing cells in the NTS also contains somatostatin- and enkephalin-immunoreactivities, and these include cells that project to the PVN [195].

The hippocampal formation has long been proposed to negatively regulate the HPA-axis [196198]. Fischette and colleagues [199] showed that fimbria-fornix lesions that disrupt ventral subicular efferents altered the circadian rhythmicity of plasma corticosterone level. More recently, Herman and colleagues $[200,201]$ have shown that hippocampal ablations or selective fimbria-fornix lesions increased CRH as well as AVP mRNA expression in the medial parvocellular division of the PVN. These results suggest that the hippocampal efferents, especially those originating from the ventral subiculum, participate tonically in inhibitory regulation of the hypothalamic $\mathrm{CRH}$ neurons. Since the hippocampus contains the highest levels of both type I and type II glucocorticoid receptors in the brain [202-205], it is likely that circulating glucocorticoids may exert their actions in the hippocampus, as well as the PVN, to inhibit the hypothalamic $\mathrm{CRH}$ neurons via efferent neural inputs to the PVN.

Electrical stimulation of the CeA induced ACTH secretion [206]. Conversely, ablation of the CeA inhibited stress-induced ACTH release [207]. An anatomical tracing study showed direct input from the CeA to the parvocellular division of the PVN [208]. Microinjection of NE into the CeA increased CRH mRNA levels in the PVN, suggesting that the $\mathrm{CeA}$ may relay the noradrenergic input from the brainstem to the hypothalamic CRH neurons (Itoi et al., unpublished observations). These data all favor the hypothesis that the CeA positively regulate hypothalamic $\mathrm{CRH}$ neurons. However, CeA lesions neither affected ACTH secretion nor CRH mRNA levels in the PVN [209], thus the CeA may not regulate the basal HPA tone. The medial amygdaloid nucleus also appears to be involved in the stimulation of the HPA-axis, but other subdivisions of the amygdala may play an inhibitory role, thus the amygdaloid subnuclei may influence the hypothalamic $\mathrm{CRH}$ neurons differentially [210].

Whereas anterolateral BNST lesion correlated with decreased CRH mRNA levels in the PVN, 
posterior intermediate and/or posterior medial BNST lesion correlated with increased CRH mRNA levels, suggesting differential BNST input into the HPA regulation [211]. The septum, and medial prefrontal cortex appear to have a negative effect on HPA activity (for review, see ref. [209]). There are local intrahypothalamic neural networks which may integrate numerous inputs conveyed to the hypothalamus from other parts of the brain as well as from the periphery. These neural circuitries within the hypothalamus are reviewed by Herman and colleagues [209].

\section{Summary}

CRH is produced in the parvocellular division of the PVN and released into the hypophysial portal circulation to stimulate ACTH synthesis and secretion, thus playing a critical role in the HPA axis regulation. The activity of $\mathrm{CRH}$ neurons is regulated by humoral factors such as glucocorticoid and IL-1 as well as numerous kinds of neural inputs within and from outside of the hypothalamus. Circulating glucocorticoids readily have access to the $\mathrm{CRH}$ neurons and thereby exert a potent inhibitory action on CRH gene transcription. The molecular mechanisms involved in the glucocorticoid negative feedback remain to be fully understood. IL-1, produced in the periphery during the inflammatory process, is a potent stimulatory factor for CRH neurons. It is not yet clear how a protein of this large molecular weight has access to brain tissues through the blood brain barrier, nor is it clear through which neural pathway the IL-1-mediated signal is conveyed to the hypothalamus.

A number of neurotransmitter/modulator candidates have been implicated in the regulation of $\mathrm{CRH}$ neurons. Functional roles and anatomical pathways have been explored by pharmacological methods, ablation of specific neural pathway(s), and the neural tracing method. Despite the substantial knowledge produced by these studies, physiological and/or pathophysiological roles of the respective neural circuitry are still obscure.

Two major intracellular signal transduction systems, the cAMP-dependent PKA pathway and diacylglycerol-dependent PKC pathway, are implicated in transcriptional regulation of the $\mathrm{CRH}$ gene. The functionality of the CRE, 5 '-flanking the CRH gene, has been well established in cell culture system transfected with CRH promoter-reporter constructs, thus the cAMP-dependent PKA pathway may play an essential role in $\mathrm{CRH}$ gene expression. The role of the PKC pathway is still controversial and requires further exploration.

\section{References}

1. Olschowka JA, O'Donohue TL, Mueller GP, Jacobowitz DM (1982) Hypothalamic and extrahypothalamic distribution of CRF-like immunoreactive neurons in the rat brain. Neuroendocrinology 35: 305-308.

2. Merchenthaler I, Vigh S, Petrusz P, Schally AV (1982) Immunocytochemical localization of corticotropin-releasing factor (CRF) in the rat brain. Am J Anat 165: 385-396.

3. Swanson LW, Sawchenko PE, Rivier J, Vale WW (1983) Organization of ovine corticotropin-releasing factor immunoreactive cells and fibers in the rat brain: An immunohistochemical study. Neuroendocrinology 36: 165-186.

4. Bloom FE, Battenberg ELF, Rivier J, Vale W (1982) Corticotropin-releasing factor (CRF): Immunoreactive neurons and fibers in rat hypothalamus. Regul Pept 4: 43-48.

5. Vale W, Spiess J, Rivier C, Rivier J (1981)
Characterization of a 41-residue ovine hypothalamic peptide that stimulates secretion of corticotropin and beta-endorphin. Science 213: 1394-1397.

6. Furutani Y, Morimoto $Y$, Shibahara S, Noda M, Takahashi $H$, Hirose $T$, Asai $M$, Inayama $S$, Hayashida H, Miyata T, Numa S (1983) Cloning and sequence analysis of cDNA for ovine corticotropin-releasing factor precursor. Nature 301: 537-540.

7. Jingami $H$, Mizuno N, Takahashi $H$, Shibahara S, Furutani Y, Imura H, Numa S (1985) Cloning and sequence analysis of cDNA for rat corticotropinreleasing factor precursor. FEBS Lett 191: 63-66.

8. Shibahara S, Morimoto Y, Furutani Y, Notake M, Takahashi H, Shimizu S, Horikawa S, Numa S (1983) Isolation and sequence of the human corticotropinreleasing factor precursor gene. EMBO I 2: 775779.

9. Thompson RC, Seasholtz AF, Herbert E (1987) Rat 
corticotropin-releasing hormone gene: Sequence and tissue-specific expression. Mol Endocrinol 1: 363-370.

10. Roche PJ, Crawford RJ, Fernley RT, Tregear GW, Coghlan JP (1988) Nucleotide sequence of the gene coding for ovine corticotropin-releasing factor and regulation of its mRNA levels by glucocorticoids. Gene 71: 421-431.

11. Seasholtz AF, Bourbonais FJ, Harnden CE, Camper SA (1991) Nucleotide sequence and expression of the mouse corticotropin-releasing hormone gene. Mol Cell Neurosci 2: 266-273.

12. Rivier CL, Plotsky PM (1986) Mediation by corticotropin-releasing factor (CRF) of adrenohypophysial hormone secretion. Ann Rev Physiol 48: 475-494.

13. Antoni FA (1986) Hypothalamic control of adrenocorticotropin secretion: Advances since the discovery of 41-residue corticotropin-releasing factor. Endocr Rev 7: 351-378.

14. Arbiser JL, Morton CC, Bruns GA, Majzoub JA (1988) Human corticotropin releasing hormone gene is located on the long arm of chromosome 8 . Cytogenet Cell Genet 47: 113-116.

15. Knapp LT, Keegan CE, Seasholtz AF, Camper SA (1993) Corticotropin-releasing hormone (Crh) maps to mouse chromosome 3. Mamm Genome 4: 615617.

16. Vamvakopoulos NC, Chrousos GP (1994) Hormonal regulation of human corticotropin-releasing hormone gene expression: Implications for the stress response and immune/inflammatory reaction. Endocr Rev 15: 409-420.

17. Sawchenko PE, Swanson LW, Vale WW (1984) Corticotropin-releasing factor: Coexpression within distinct subsets of oxytocin-, vasopressin-, and neurotensin-immunoreactive neurons in the hypothalamus of the male rat. J Neurosci 4: 11181129.

18. Mouri T, Suda T, Sasano N, Andoh N, Takei $Y$, Takase M, Sasaki A, Murakami O, Yoshinaga K (1984) Immunocytochemical identification of CRF in the human hypothalamus. Tohoku J Exp Med 142: 423-426.

19. Pelletier G, Desy L, Cote J, Vaudry H (1983) Immunocytochemical localization of corticotropinreleasing factor-like immunoreactivity in the human hypothalamus. Neurosci Lett 41: 259-263.

20. Mouri T, Itoi K, Takahashi K, Suda T, Murakami O, Yoshinaga K, Andoh N, Ohtani H, Masuda T, Sasano N (1993) Colocalization of corticotropinreleasing factor and vasopressin in the paraventricular nucleus of the human hypothalamus. Neuroendocrinology 57: 34-39.

21. Cummings S, Elde R, Ells J, Lindall A (1983) Corticotropin-releasing factor immunoreactivity is widely distributed within the central nervous system of the rat: An immunohistochemical study.
J Neurosci 3: 1355-1368.

22. Sakanaka M, Shibasaki T, Lederis K (1987) Corticotropin releasing factor-like immunoreactivity in the rat brain as revealed by a modified cobaltglucose oxidase-diaminobenzidine method. J Comp Neurol 260: 256-298.

23. Young WS III, Walker LC, Powers RE, De Souza EB, Price DL (1986) Corticotropin-releasing factor mRNA is expressed in the inferior olives of rodents and primates. Brain Res 387: 189-192.

24. Mezey E, Palkovits M (1991) Time dependent changes in CRF and its mRNA in the neurons of the inferior olive following surgical transection of the olivocerebellar tract in the rat. Mol Brain Res 10: 55-59.

25. Ju G, Swanson LW, Simerly RB (1989) Studies on the cellular architecture of the bed nuclei of the stria terminalis of the rat: II. Chemoarchitecture. J Comp Neurol 280: 603-621.

26. Imaki J, Imaki T, Vale W, Sawchenko PE (1991) Distribution of corticotropin-releasing factor mRNA and immunoreactivity in the central auditory system of the rat. Brain Res 547: 28-36.

27. Palkovits M, Leranth C, Gorcs T, Young WS III (1987) Corticotropin-releasing factor in the olivocerebellar tract of rats: Demonstration by lightand electron-microscopic immunohistochemistry and in situ hybridization histochemistry. Proc Natl Acad Sci USA 84: 3911-3915.

28. Keegan CE, Herman JP, Karolyi IJ, O'Shea KS, Camper SA, Seasholtz AF (1994) Differential expression of corticotropin-releasing hormone in developing mouse embryos and adult brain. Endocrinology 134: 2547-2555.

29. Suda T, Yajima F, Tomori N, Demura H, Shizume $\mathrm{K}$ (1985) In vitro study of immunoreactive corticotropin-releasing factor release from the rat hypothalamus. Life Sci 37: 1499-1505.

30. Emanuel RL, Girard DM, Thull DL, Majzoub JA (1990) Second messengers involved in the regulation of corticotropin-releasing hormone mRNA and peptide in cultured rat fetal hypothalamic primary cultures. Endocrinology 126: 3016-3021.

31. Seasholtz AF, Thompson RC, Douglass JO (1988) Identification of a cyclic adenosine monophosphateresponsive element in the rat corticotropin-releasing hormone gene. Mol Endocrinol 2: 1311-1319.

32. Spengler D, Rupprecht R, Van LP, Holsboer F (1992) Identification and characterization of a $3^{\prime}, 5^{\prime}$-cyclic adenosine monophosphate-responsive element in the human corticotropin-releasing hormone gene promoter. Mol Endocrinol 6: 1931-1941.

33. Dorin RI, Takahashi H, Nakai Y, Fukata J, Naitoh Y, Imura H (1989) Regulation of human corticotropin-releasing hormone gene expression by $3^{\prime}, 5^{\prime}$-cyclic adenosine monophosphate in a transfected mouse corticotroph cell line. Mol 
Endocrionol 3: 1537-1544.

34. Van LP, Spengler DH, Holsboer F (1990) Glucocorticoid repression of $3^{\prime}, 5^{\prime}$-cyclic-adenosine monophosphate-dependent human corticotropinreleasing-hormone gene promoter activity in a transfected mouse anterior pituitary cell line. Endocrinology 127: 1412-1418.

35. Guardiola-Diaz HM, Boswell C, Seasholtz AF (1994) The cAMP-responsive element in the corticotropinreleasing hormone gene mediates transcriptional regulation by depolarization. J Biol Chem 269: 14784 14791.

36. Itoi K, Horiba N, Tozawa F, Sakai Y, Sakai K, Abe K, Demura H, Suda T (1996) Major role of 3',5'cyclic adenosine monophosphate-dependent protein kinase A pathway in corticotropin-releasing factor gene expression in the rat hypothalamus. Endocrinology 137: 2389-2396.

37. Kovacs KJ, Sawchenko PE (1996) Sequence of stressinduced alterations in indices of synaptic and transcriptional activation in parvocellular neurosecretory neurons. J Neurosci 16: 262-273.

38. Vamvakopoulos NC, Chrousos GP (1993) Structural organization of the $5^{\prime}$ flanking region of the human corticotropin releasing hormone gene. DNA Sequence J 4: 197-206.

39. Vamvakopoulos NC, Chrousos GP (1993) Regulated activity of the distal promoter-like element of the human corticotropin-releasing hormone gene and secondary structural features of its corresponding transcripts. Mol Cell Endocrinol 94: 73-78.

40. Rosen LB, Majzoub JA, Adler GK (1992) Effects of glucocorticoid on corticotropin-releasing hormone gene regulation by second messenger pathways in NPLC and AtT-20 cells. Endocrinology 130: 22372244.

41. Adler GK, Rosen LB, Fiandaca MJ, Majzoub JA (1992) Protein kinase-C activation increases the quantity and poly (A) tail length of corticotropinreleasing hormone messenger RNA in NPLC cells. Mol Endocrinology 6: 476-484.

42. Suda T, Tozawa F, Yamada M, Ushiyama T, Tomori N, Sumitomo T, Nakagami Y, Demura H, Shizume $\mathrm{K}$ (1988) Insulin-induced hypoglycemia increases corticotropin-releasing factor messenger ribonucleic acid levels in rat hypothalamus. Endocrinology 123: 1371-1375.

43. Herman JP, Schafer MK-H, Thompson RC, Watson SJ (1992) Rapid regulation of corticotropin-releasing hormone gene transcription in vivo. Mol Endocrinol 6: 1061-1069.

44. Bugnon C, Fellmann D, Gouget A (1983) Changes in corticoliberin and vasopressin-like immunoreactivities in the zona externa of the median eminence in adrenalectomized rats. Immunocytochemical study. Neurosci Lett 37: 43-49.

45. Kiss JZ, Mezey E, Skirboll L (1984) Corticotropin- releasing factor-immunoreactive neurons of the paraventricular nucleus become vasopressin positive after adrenalectomy. Proc Natl Acad Sci USA 81: 1854-1858.

46. Itoi K, Mouri T, Takahashi K, Murakami O, Imai $Y$, Sasaki S, Yoshinaga K, Sasano N (1987) Suppression by glucocorticoid of the immunoreactivity of corticotropin-releasing factor and vasopressin in the paraventricular nucleus of rat hypothalamus. Neurosci Lett 73: 231-236.

47. Jingami H, Matsukura S, Numa S, Imura H (1985) Effects of adrenalectomy and dexamethasone administration on the level of prepro-corticotropinreleasing factor messenger ribonucleic acid (mRNA) in the hypothalamus and adrenocorticotropin/blipotropin precursor mRNA in the pituitary in rats. Endocrinology 117: 1314-1320.

48. Swanson LW, Simmons DM (1989) Differential steroid hormone and neural influence on peptide mRNA levels in CRH cells of the paraventricular nucleus: A hybridization histochemical study in the rat. J Comp Neurol 285: 413-435.

49. Beyer HS, Matta SG, Sharp BM (1988) Regulation of the messenger ribonucleic acid for corticotropinreleasing factor in the paraventricular nucleus and other brain sites of the rat. Endocrinology 123: 21172123.

50. Plotsky PM, Sawchenko PE (1987) Hypophysialportal plasma levels, median eminence content, and immunohistochemical staining of corticotropinreleasing factor, arginine vasopressin, and oxytocin after pharmacological adrenalectomy. Endocrinology 120: 1361-1369.

51. Kovacs K, Kiss JZ, Makara GB (1986) Glucocorticoid implants around the hypothalamic paraventricular nucleus prevent the increase of corticotropinreleasing factor and arginine vasopressin immunostaining induced by adrenalectomy. Neuroendocrinology 44: 229-234.

52. Kovacs KJ, Mezey E (1987) Dexamethasone inhibits corticotropin-releasing factor gene expression in the rat paraventricular nucleus. Neuroendocrinology 46: 365-368.

53. Sawchenko PE (1987) Evidence for a local site of action for glucocorticoids in inhibiting CRF and vasopressin expression in the paraventricular nucleus. Brain Res 403: 213-224.

54. Adler GK, Smas CM, Majzoub JA (1988) Expression and dexamethasone regulation of the human corticotropin-releasing hormone gene in a mouse anterior pituitary cell line. J Biol Chem 263: 58465852.

55. Roberts JL, Budarf ML, Baxter JD, Herbert E (1979) Selective reduction of proadrenocorticotropin/ endorphin proteins and mRNA activity in mouse pituitary tumor cells by glucocorticoids. Biochemistry 18: 4907-4915. 
56. Birnberg NC, Lissitzky JC, Hinman M, Herbert E (1983) Glucocorticoids regulate proopiomelanocortin gene expression in vivo at the levels of transcription and secretion. Proc Natl Acad Sci USA 80: 6982-6986.

57. Drouin J, Trifiro MA, Plante RK, Nemer M, Eriksson P, Wrange O (1989) Glucocorticoid receptor binding to a specific DNA sequence is required for hormonedependent repression of pro-opiomelanocortin gene transcription. Mol Cell Biol 9: 5305-5314.

58. Jonat C, Rahmsdorf HJ, Park K-K, Cato ACB, Gebel S, Ponta H, Herrlich P (1990) Antitumor promotion and antiinflammation: Down-modulation of AP-1 (fos/jun) activity by glucocorticoid hormone. Cell 62: 1189-1204.

59. Akerblom IE, Slater EP, Beato M, Baxter JD, Mellon PL (1988) Negative regulation by glucocorticoids through interference with a cAMP responsive enhancer. Science 241: 350-353.

60. Chatterjee VK, Madison LD, Mayo S, Jameson JL (1991) Repression of the human glycoprotein hormone alpha subunit gene by glucocorticoids: Evidence for receptor interactions with limiting transcriptional activators. Mol Endocrinol 5: 100-110.

61. Camper SA, Yao YAS, Rottman FM (1985) Hormonal regulation of the bovine prolactin promoter in rat pituitary tumor cells. $J$ Biol Chem 260: 12246-12251.

62. Sakai DD, Helms S, Carlstedt-Duke J, Gustafsson JA, Rottman FM, Yamamoto KR (1988) Hormonemediated repression: A negative glucocorticoid responsive element from the bovine prolactin gene. Genes Dev 2: 1144-1154.

63. Diamond MI, Miner JN, Yoshinaga SK, Yamamoto KR (1990) Transcription factor interactions: Selectors of positive or negative regulation from a single DNA element. Science 249: 1266-1272.

64. Morrison N, Eisman J (1993) Role of the negative glucocorticoid regulatory element in glucocorticoid repression of the human osteocalcin promoter. $J$ Bone Miner Res 8: 969-975.

65. Guardiola-Diaz HM, Kolinske JS, Gates LH, Seasholtz AF (1996) Negative glucocorticoid regulation of cyclic adenosine 3',5'-monophosphatestimulated corticotropin-releasing hormone-reporter expression in AtT-20 cells. Mol Endocrinol 10: 317329.

66. Malkoski SP, Handanos CM, Dorin RI (1997) Localization of a negative glucocorticoid response element of the human corticotropin releasing hormone gene. Mol Cell Endocrinol 127: 189-199.

67. Grino M, Young WS III, Burgunder J-M (1989) Ontogeny of expression of the corticotropinreleasing factor gene in the hypothalamic paraventricular nucleus and of the proopiomelanocortin gene in rat pituitary. Endocrinology 124: 60-68.

68. Daikoku S, Okamura Y, Kawano H, Tsuruo Y,
Maegawa M, Shibasaki T (1984) Immunohistochemical study on the development of CRFcontaining neurons in the hypothalamus of the rat. Cell Tissue Res 238: 539-544.

69. Bugnon C, Fellmann D, Gouget A, Cardot J (1982) Ontogeny of the corticoliberin neuroglandular system in rat brain. Nature 298: 159-161.

70. Walker C-D, Perrin M, Vale W, Rivier C (1986) Ontogeny of the stress response in the rat: Role of the pituitary and the hypothalamus. Endocrinology 118: 1445-1451.

71. Sapolsky RM, Meaney MJ (1986) Maturation of the adrenocortical stress response: Neuroendocrine control mechanisms and the stress hyporesponsive period. Brain Res Rev 11: 65-76.

72. Meaney MJ, Sapolsky RM, McEwen BS (1985) The development of the glucocorticoid receptor system in the rat limbic brain. I. Ontogeny and autoregulation. Brain Res 350: 159-164.

73. Keegan CE, Karolyi IJ, Knapp LT, Bourbonais FJ, Camper SA, Seasholtz AF (1994) Expression of corticotropin-releasing hormone transgenes in neurons of adult and developing mice. Mol Cell Neurosci 5: 505-514.

74. Keegan CE, Karolyi IJ, Burrows HL, Camper SA, Seasholtz AF (1994) Homologous recombination in fertilized mouse eggs and assessment of heterologous locus control region function. Transgenics 1: 439-449.

75. Plotsky PM, Cunningham ET Jr, Widmaier EP (1989) Catecholaminergic modulation of corticotropinreleasing factor and adrenocorticotropin secretion. Endocr Rev 10: 437-458.

76. Sawchenko PE, Swanson LW (1981) Central noradrenergic pathways for the integration of hypothalamic neuroendocrine and autonomic responses. Science 214: 685-687.

77. Sawchenko PE, Swanson LW (1982) The organization of noradrenergic pathways from the brainstem to the paraventricular and supraoptic nuclei in the rat. Brain Res Rev 4: 275-325.

78. Swanson LW, Sawchenko PE (1983) Hypothalamic integration: Organization of the paraventricular and supraoptic nuclei. Annu Rev Neurosci 6: 269-324.

79. Cunningham ET Jr, Sawchenko PE (1988) Anatomical specificity of noradrenergic inputs to the paraventricular and supraoptic nuclei of the rat hypothalamus. J Comp Neurol 274: 60-76

80. Cunningham ET Jr, Bohn MC, Sawchenko PE (1990) Organization of adrenergic inputs to the paraventricular and supraoptic nuclei of the hypothalamus in the rat. J Comp Neurol 292: 651667.

81. Liposits Z, Phelix C, Paull WK (1986) Electron microscopic analysis of tyrosine hydroxylase, dopamine- $\beta$-hydroxylase and phenylethanolamine$\mathrm{N}$-methyltransferase immunoreactive innervation of 
the hypothalamic paraventricular nucleus in the rat. Histochemistry 84: 105-120.

82. Van Loon GR, Scapagnini U, Cohen R, Ganong WF (1971) Effect of intraventricular administration of adrenergic drugs on the adrenal venous 17 hydroxycorticosteroid response to surgical stress in the dog. Neuroendocrinology 8: 257-272.

83. Szafarczyk A, Malaval F, Laurent A, Gibaud R, Assenmacher I (1987) Further evidence for a central stimulatory action of catecholamines on adrenocorticotropin release in the rat. Endocrinology 121: 883-892.

84. Leibowitz SF, Diaz S, Tempel D (1989) Norepinephrine in the paraventricular nucleus stimulates corticosterone. Brain Res 496: 219-227.

85. Itoi K, Suda T, Tozawa F, Dobashi I, Ohmori N, Sakai Y, Abe K, Demura H (1994) Microinjection of norepinephrine into the paraventricular nucleus of the hypothalamus stimulates corticotropin-releasing factor gene expression in conscious rats. Endocrinology 135: 2177-2182.

86. Liu J-P, Clarke IJ, Funder JW, Engler D (1991) Evidence that the central noradrenergic pathways activate the hypothalamic-pituitary-adrenal axis in the sheep. Endocrinology 129: 200-209.

87. Plotsky PM (1987) Facilitation of immunoreactive corticotropin-releasing factor secretion into the hypophysial-portal circulation after activation of catecholaminergic pathways or central norepinephrine injection. Endocrinology 121: 924930.

88. Widmaier EP, Lim AT, Vale W (1989) Secretion of corticotropin-releasing factor from cultured rat hypothalamic cells: Effects of catecholamines. Endocrinology 124: 583-590.

89. Buckingham JC, Hodges JR (1979) Hypothalamic receptors influencing the secretion of corticotrophin releasing hormone in the rat. J Physiol (Lond) 290: 421-431.

90. Fehm HL, Voigt KH, Lang RE, Pfeiffer EF (1980) Effects of neurotransmitters on the release of corticotropin releasing hormone $(\mathrm{CRH})$ by rat hypothalamic tissue in vitro. Exp Brain Res 39: 229234.

91. Suda T, Yajima F, Tomori N, Sumitomo T, Nakagami Y, Ushiyama T, Demura H, Shizume K (1987) Inhibitory effect of norepinephrine on immunoreactive corticotropin-releasing factor release from the rat hypothalamus in vitro. Life Sci 40: 1645-1649.

92. Tsagarakis S, Holly JMP, Rees LH, Besser GM, Grossman A (1988) Acetylcholine and norepinephrine stimulate the release of corticotropinreleasing factor-41 from the rat hypothalamus in vitro. Endocrinology 123: 1962-1969.

93. Calogero AE, Gallucci WT, Chrousos GP, Gold PW (1988) Catecholamine effects upon rat hypothalamic corticotropin-releasing hormone secretion in vitro. J Clin Invest 82: 839-846.

94. Palkovits M (1987) Anatomy of neural pathways affecting CRH secretion. Ann NY Acad Sci 512: 139148.

95. Alonso G, Szafarczyk A, Balmefrezol M, Assenmacher I (1986) Immunocytochemical evidence for stimulatory control by the ventral noradrenergic bundle of parvocellular neurons of the paraventricular nucleus secreting corticotropin releasing hormone and vasopressin in rats. Brain Res 397: 297-307.

96. Szafarczyk A, Alonso G, Ixart G, Malaval F, Assenmacher I (1985) Diurnal-stimulated and stressinduced ACTH release in rats is mediated by ventral noradrenergic bundle. Am J Physiol 249: E219-E226.

97. Sawchenko PE (1988) Effects of catecholaminedepleting medullary knife cuts on corticotropinreleasing factor and vasopressin immunoreactivity in the hypothalamus of normal and steroidmanipulated rats. Neuroendocrinology 48: 459-470.

98. Pacak K, Armando I, Fukuhara K, Kvetnansky R, Palkovits M, Kopin I, Goldstein DS (1992) Noradrenergic activation in the paraventricular nucleus during acute and chronic immobilization stress in rats: An in vivo microdialysis study. Brain Res 589: 91-96.

99. Pacak K, Palkovits M, Kvetnansky R, Kopin IJ, Goldstein DS (1993) Stress-induced norepinephrine release in the paraventricular nucleus of rats with brainstem hemisections: A microdialysis study. Neuroendocrinology 58: 196-201.

100. Guillaume V, Conte-Devolx B, Szafarczyk A, Malaval F, Pares-Herbute N, Grino M, Alonso G, Assenmacher I, Oliver C (1987) The corticotropinreleasing factor release in rat hypophysial portal blood is mediated by brain catecholamines. Neuroendocrinology 46: 143-146.

101. Harbuz MS, Chowdrey HS, Jessop DS, Biswas S, Lightman SL (1991) Role of catecholamines in mediating messenger RNA and hormonal responses to stress. Brain Res 551: 52-57.

102. Mezey E, Kiss JS, Skirboll LR, Goldstein M, Axelrod J (1984) Increase of corticotropin-releasing factor staining in rat paraventricular nucleus neurones by depletion of hypothalamic adrenaline. Nature 310: 140-141.

103. Plotsky PM, Otto S, Sutton S (1987) Neurotransmitter modulation of corticotropin releasing factor secretion into the hypophysialportal circulation. Life Sci 41: 1311-1317.

104. Spinedi E, Johnston CA, Chisari A, Negro-Vilar A (1988) Role of central epinephrine on the regulation of corticotropin-releasing factor and adrenocorticotropin secretion. Endocrinology 122: 1977-1983.

105. Kiss A, Aguilera G (1992) Participation of $\alpha 1$ - 
adrenergic receptors in the secretion of hypothalamic corticotropin-releasing hormone during stress. Neuroendocrinology 56: 153-160.

106. Whitnall MH, Kiss A, Aguilera G (1993) Contrasting effects of central alpha-1-adrenoreceptor activation on stress-responsive and stress-nonresponsive subpopulations of corticotropin-releasing hormone neurosecretory cells in the rat. Neuroendocrinology 58: 42-48.

107. Young WS III, Kuhar MJ (1980) Noradrenergic $\alpha 1$ and $\alpha 2$ receptors: Light microscopic autoradiographic localization. Proc Natl Acad Sci USA 77: 1696-1700.

108. Leibowitz SF, Jhanwar-Uniyal M, Dvorkin B, Makman MH (1982) Distribution of $\alpha$-adrenergic, $\beta$-adrenergic and dopaminergic receptors in discrete hypothalamic areas of rat. Brain Res 233: 97-114.

109. Petrovic SL, McDonald JK, Snyder GD, McCann SM (1983) Characterization of $\beta$-adrenergic receptors in rat brain and pituitary using a new high-affinity ligand, [125I]iodocyanopindolol. Brain Res 261: 249-259.

110. Jones LS, Gauger LL, Davis JN (1985) Anatomy of brain alphat-adrenergic receptors: In vitro autoradiography with [125I]-HEAT. J Comp Neurol 231: 190-208.

111. Lachuer J, Gaillet S, Barbagli B, Buda M, Tappaz M (1991) Differential early time course activation of the brainstem catecholaminergic groups in response to various stresses. Neuroendocrinology 53: 589-596.

112. Hillhouse EW, Burden J, Jones MT (1975) The effect of various putative neurotransmitters on the release of corticotropin releasing hormone from the hypothalamus of the rat in vitro. I. The effect of acetylcholine and noradrenaline. Neuroendocrinology 17: 1-11.

113. Calogero AE, Gallucci WT, Bernardini R, Saoutis C, Gold PW, Chrousos GP (1988) Effect of cholinergic agonists and antagonists on rat hypothalamic corticotropin-releasing hormone secretion in vitro. Neuroendocrinology 47: 303-308.

114. Hillhouse EW, Milton NGN (1989) Effect of acetylcholine and 5-hydroxytryptamine on the secretion of corticotropin-releasing factor-41 and arginine vasopressin from the rat hypothalamus in vitro. J Endocrinol 122: 713-718.

115. Suda T, Yajima F, Tomori N, Sumitomo T, Nakagami Y, Ushiyama T, Demura H, Shizume K (1987) Stimulatory effect of acetylcholine on immunoreactive corticotropin-releasing factor release from the rat hypothalamus in vitro. Life Sci 40: 673-677.

116. Hillhouse E, Reichlin S (1990) Acetylcholine stimulates the secretion of corticotropin-releasing factor from primary dissociated cell culture of the rat telencephalon and diencephalon. Brain Res 506: 9-13.
117. Hedge GA, Smelik PG (1968) Corticotropin release: Inhibition by intrahypothalamic implantation of atropine. Science 159: 891-892.

118. Calogero AE, Kamilaris TC, Gomez MT, Johnson EO, Tartaglia ME, Gold PW, Chrousos GP (1989) The muscarinic cholinergic agonist arecoline stimulates the rat hypothalamic-pituitary-adrenal axis through a centrally-mediated corticotropinreleasing hormone-dependent mechanism. Endocrinology 125: 2445-2453.

119. Ohmori N, Itoi K, Tozawa F, Sakai Y, Sakai K, Horiba N, Demura H, Suda T (1995) Effect of acetylcholine on corticotropin-releasing factor gene expression in the hypothalamic paraventricular nucleus of conscious rats. Endocrinology 136: 4858 4863.

120. Hunt S, Schmidt J (1978) Some observations on the binding patterns of $\alpha$-bungarotoxin in the central nervous system of the rat. Brain Res 157: 213-232.

121. Rotter A, Birdsall NJM, Burgen ASV, Field PM, Hulme EC, Raisman G (1979) Muscarinic receptors in the central nervous system of the rat. I. Technique for autoradiographic localization of the binding of [3 $\mathrm{H}$ ]propylbenzilylcholine mustard and its distribution in the forebrain. Brain Res Rev 1: 141165.

122. Mash DC, Potter LT (1986) Autoradiographic localization of M1 and M2 muscarine receptors in the rat brain. Neuroscience 19: 551-564.

123. Ball GF, Nock B, Wingfield JC, McEwen BS, Balthazart J (1990) Muscarinic cholinergic receptors in the songbird and quail brain: A quantitative autoradiographic study. J Comp Neurol 298: 431442.

124. Wada E, Wada K, Boulter J, Deneris E, Heinemann S, Patrick J, Swanson LW (1989) Distribution of alpha2, alpha3, alpha4, and beta2, neuronal nicotinic receptor subunit mRNAs in the central nervous system: A hybridization histochemical study in the rat. J Comp Neurol 284: 314-335.

125. Okuda H, Shioda S, Nakai $Y$, Nakayama $H$, Okamoto M, Nakashima T (1993) Immuocytochemical localization of nicotinic acetylcholine receptor in rat hypothalamus. Brain Res 625: 145151.

126. Vilaro MT, Palacios JM, Mengot G (1990) Localization of $\mathrm{m} 5$ muscarinic receptor mRNA in rat brain examined by in situ hybridization histochemistry. Neurosci Lett 114: 154-159.

127. Vilaro MT, Wiederhold K-H, Palacios JM, Mengold $\mathrm{G}$ (1992) Muscarinic $\mathrm{M}_{2}$ receptor mRNA expression and receptor binding in cholinergic and noncholinergic cells in the rat brain. A correlative study using in situ hybridization histochemistry and receptor autoradiography. Neuroscience 47: 367-393.

128. Ruggiero DA, Giuliano R, Anwar M, Stornetta R, Reis DJ (1990) Anatomical substrates of cholinergic- 
autonomic regulation in the rat. J Comp Neurol 292: $1-53$.

129. Oorjithan EG, Dodfrey DA, Ross CD, Dunn JD (1989) Effect of septal ablation on choline acetyltransferase in the paraventricular nucleus. Brain Res Bull 22: 277-282.

130. Butcher LL, Woolf NJ (1984) Histochemical distribution of acetylcholinesterase in the central nervous system: Clues to the localization of cholinergic neurons. In: Bjorklund A, Hokfelt T, Kuhar MJ (eds) Handbook of Chemical Neuroanatomy. Elsevier, Amsterdam, vol 3: 1-50.

131. Kimura H, McGeer P, Peng J-H (1984) Choline acetyltransferase-containing neurons in the rat brain. In: Bjorklund A, Hokfelt T, Kuhar MJ (eds) Handbook of Chemical Neuroanatomy. Elsevier, Amsterdam, vol 3: 51-67.

132. Rye DB, Saper CB, Lee HJ, Wainer BH (1987) Pedunculopontine tegmental nucleus of the rat: Cytoarchitecture, cytochemistry, and some extrapyramidal connections of the mesopontine tegmentum. J Comp Neurol 259: 483-528.

133. Saper CB, Loewy AD (1980) Efferent connections of the parabrachial nucleus in the rat. Brain Res 197: 291-317.

134. Sawchenko PE, Swanson LW, Steinbusch HWM, Verhofstad AAJ (1983) The distribution and cells of origin of serotonergic inputs to the paraventricular nuclei of the rat. Brain Res 277: 355-360.

135. Lipisits Z, Phelix C, Paull WK (1987) Synaptic interaction of serotonergic axons and corticotropin releasing factor (CRF) synthesizing neurons in the hypothalamic paraventricular nucleus of the rat. Histochemistry 86: 541-549.

136. Saphier D, Feldman S (1989) Paraventricular nucleus neuronal responses following electrical stimulation of the midbrain dorsal raphe: Evidence for cotransmission. Exp Brain Res 78: 407-414.

137. Nakagami $Y$, Suda T, Yajima F, Ushiyama T, Tomori $N$, Sumitomo T, Demura H, Shizume K (1986) Effects of serotonin, cyproheptadine and reserpine on corticotropin-releasing factor release from the rat hypothalamus in vitro. Brain Res 386: 232-236.

138. Gibbs DM, Vale W (1983) Effect of the serotonin reuptake inhibitor fluoxetine on corticotropinreleasing factor and vasopressin secretion into hypophysial portal blood. Brain Res 280: 176-179.

139. Korte SM, Van Duin S, Bouws GAH, Koolhaas JM, Bohus B (1991) Involvement of hypothalamic serotonin in activation of the sympathoadrenomedullary system and hypothalamicpituitary-adrenocortical axis in male Wistar rats. Eur J Pharmacol 197: 225-228.

140. Inagaki N, Yamatodani A, Ando-Yamamoto M, Tohyama M, Watanabe T, Wada H (1988) Organization of histaminergic fibers in the rat brain. J Comp Neurol 273: 283-300.
141. Kjaer A, Knigge U, Bach FW, Warberg J (1992) Histamine- and stress-induced secretion of ACTH and $\beta$-endorphin: Involvement of corticotropinreleasing hormone and vasopressin. Neuroendocrinology 56: 419-428.

142. Tozawa F, Suda T, Yamada M, Ushiyama T, Tomori N, Sumitomo T, Nakagami Y, Demura H, Shizume K (1988) Insulin-induced hypoglycemia increases proopiomelanocortin messenger ribonucleic acid levels in rat anterior pituitary gland. Endocrinology 122: 1231-1235.

143. Kjaer A, Knigge U, Madsen EL, Soe-Jensen P, Bach FW, Warberg J (1993) Insulin/hypoglycemiainduced adrenocorticotropin and $\beta$-endorphin release: Involvement of hypothalamic histaminergic neurons. Endocrinology 132: 2213-2220.

144. Kjaer A, Larsen P, Knigge U, Moller M, Warberg J (1994) Histamine stimulates c-fos expression in hypothalamic vasopressin-, oxytocin-, and corticotropin-releasing hormone-containing neurons. Endocrinology 134: 482-491.

145. Decavel C, Van Den Pol AN (1990) GABA: A dominant neurotransmitter in the hypothalamus. $J$ Comp Neurol 302: 1019-1037.

146. Calogero AE, Gallucci WT, Chrousos GP, Gold PW (1988) Interaction between GABAergic neurotransmission and rat hypothalamic corticotropin-releasing hormone secretion in vitro. Brain Res 463: 28-36.

147. Makara GB, Stark E (1974) Effect of gammaaminobutyric acid (GABA) and GABA antagonist drugs on ACTH release. Neuroendocrinology 16: 178190.

148. Stotz-Potter EH, Morin SM, DiMicco JA (1996) Effect of microinjection of muscimol into the dorsomedial or paraventricular hypothalamic nucleus on air stress-induced neuroendocrine and cardiovascular changes in rats. Brain Res 742: 219-224.

149. Swanson LW, Cowan WM (1979) The connections of the septal region in the rat. J Comp Neurol 186: 621-656.

150. Kohler C (1990) Subicular projections to the hypothalamus and brainstem: Some novel aspects revealed in the rat by the anterograde Phaseolus vulgaris leukoagglutinin (PHA-L) tracing method. Prog Brain Res 83: 59-69.

151. Cullinan WE, Herman JP, Watson SJ (1993) Ventral subicular interaction with the hypothalamic paraventricular nucleus: Evidence for a relay in the bed nucleus of the stria terminalis. J Comp Neurol 322: 1-20.

152. Berkenbosch F, Van Oers J, Del Rey A, Tilders F, Besedovsky H (1987) Corticotropin-releasing factorproducing neurons in the rat activated by interleukin-1. Science 238: 524-526.

153. Sapolsky R, Rivier C, Yamamoto G, Plotsky P, Vale W (1987) Interleukin-1 stimulates the secretion of 
hypothalamic corticotropin-releasing factor. Science 238: 522-524.

154. Bernton EW, Beach JE, Holaday JW, Smallridge RC, Fein HG (1987) Release of multiple hormones by a direct action of interleukin-1 on pituitary cells. Science 238: 519-521.

155. Suda T, Tozawa F, Ushiyama T, Sumitomo $T$, Yamada M, Demura H (1990) Interleukin-1 stimulates corticotropin-releasing factor gene expression in rat hypothalamus. Endocrinology 126: 1223-1228.

156. Winter JSD, Gow KW, Perry YS, Greenberg AH (1990) A stimulatory effect of interleukin-1 on adrenocortical cortisol secretion mediated by prostaglandins. Endocrinology 127: 1904-1909.

157. Tominaga T, Fukata J, Naito $Y$, Usui T, Murakami N, Fukushima M, Nakai Y, Hirai Y, Imura H (1991) Prostaglandin-dependent in vitro stimulation of adrenocortical steroidogenesis by interleukins. Endocrinology 128: 526-531.

158. Uehara A, Gottshall PE, Dahl RR, Arimura A (1987) Interleukin-1 stimulates ACTH release by an action which requires endogenous corticotropin releasing factor. Endocrinology 121: 1580-1582.

159. Rivest S, Rivier C (1991) Influence of paraventricular nucleus of the hypothalamus in the alteration of neuroendocrine functions induced by intermittent footshock or interleukin. Endocrinology 129: 20492057.

160. Katsuura G, Arimura A, Koves K, Gottshall PE (1990) Involvement of organum vasculosum of lamina terminalis and preoptic area in interleukin $1 \beta$-induced ACTH release. Am J Physiol 258: E163E171.

161. Ericsson A, Liu C, Hart RP, Sawchenko PE (1995) Type 1 interleukin-1 receptor in the rat brain: Distribution, regulation and relationship to sites of IL-1-induced cellular activation. J Comp Neurol 361: 681-698.

162. Weidenfeld J, Abramsky O, Ovadia H (1989) Evidence for the involvement of the central adrenergic system in interleukin 1-induced adrenocortical response. Neuropharmacology 28: 1411-1414.

163. Chuluyan HE, Saphier D, Rohn WM, Dunn AJ (1992) Noradrenergic innervation of the hypothalamus participates in adrenocortical responses to interleukin-1. Neuroendocrinology 56: 106-111.

164. Ericsson A, Kovacs KJ, Sawchenko PE (1994) A functional anatomical analysis of central pathways subserving the effects of interleukin-1 on stressrelated neuroendocrine neurons. J Neurosci 14: 897913.

165. Ban E, Milon G, Prudhomme N, Fillion G, Haour F (1991) Receptors for interleukin-1 ( $\alpha$ and $\beta$ ) in mouse brain: Mapping and neuronal localization in hippocampus. Neuroscience 43: 21-30.

166. Cunningham ET Jr, Wada E, Carter DB, Tracey DE, Battey JF, De Souza EB (1992) In situ hiostochemical localization of type I interleukin-1 receptor messenger RNA in the central nervous system, pituitary and adrenal gland of the mouse. J Neurosci 12: 1101-1114.

167. Sawchenko PE, Swanson LW, Grzanna R, Howe PRC, Bloom SR, Polak JM (1985) Colocalization of neuropeptide $\mathrm{Y}$ immunoreactivity in brainstem catecholaminergic neurons that project to the paraventricular nucleus of the hypothalamus. $J$ Comp Neurol 241: 138-153.

168. Bai FL, Yamano M, Shiotani Y, Emson PC, Smith AD, Powell JF, Tohyama M (1985) An arcuatoparaventricular and dorsomedial hypothalamic neuropeptide Y-containing system which lacks noradrenaline in the rat. Brain Res 331: 172-175.

169. Sawchenko PE, Pfeiffer SW (1988) Ultrastructural localization of neuropeptide $Y$ and galanin immunoreactivity in the paraventricular nucleus of the hypothalamus in the rat. Brain Res 474: 231245.

170. Suda T, Tozawa F, Iwai I, Sato $Y$, Sumitomo $T$, Nakano Y, Yamada M, Demura H (1993) Neuropeptide $Y$ increases the corticotropinreleasing factor messenger ribonucleic acid level in the rat hypothalamus. Mol Brain Res 18: 311-315.

171. Lind RW, Swanson LW, Ganten D (1984) Angiotensin II immunoreactive pathways in the central nervous system of the rat: Evidence for a projection from the subfornical organ to the paraventricular nucleus of the hypothalamus. Clin Exp Hypertens A6: 1915-1920.

172. Sgro S, Ferguson AV, Renaud LP (1984) Subfornical organ-supraoptic nucleus connections: An electrophysiological study in the rat. Brain Res 303: 7-13.

173. Renaud LP, Ferguson AV, Day TA, Bourque CW, Sgro S (1985) Electrophysiology of the subfornical organ and its hypothalamic connections-An in vivo study in the rat. Brain Res Bull 15: 83-86.

174. Mendelsohn FAO, Quirion R, Saavedra JM, Aguilera G, Catt KJ (1984) Autoradiographic localization of angiotensin II receptors in rat brain. Proc Natl Acad Sci USA 81: 1575-1579.

175. Ferguson AV, Renaud LP (1986) Systemic angiotensin acts at subfornical organ to facilitate activity of neurohypophysial neurons. Am J Physiol 251: R712-R717.

176. Sumitomo T, Suda T, Nakano $Y$, Tozawa F, Yamada M, Demura H (1991) Angiotensin II increases the corticotropin-releasing factor messenger ribonucleic acid level in the rat hypothalamus. Endocrinology 128: 2248-2252.

177. Aguilera G, Young WS, Kiss A, Bathia A (1995) Direct regulation of hypothalamic corticotropin- 
releasing-hormone neurons by angiotensin II. Neuroendocrinology 61: 437-444.

178. Sawchenko PE, Swanson LW, Joseph SA (1982) The distribution and cells of origin of ACTH(1-39)stained varicosities in the paraventricular and supraoptic nuclei. Brain Res 232: 365-374.

179. Kiss JZ, Cassell MD, Palkovits M (1984) Analysis of the ACTH/ $\beta$-End/ $\alpha$-MSH immunoreactive afferent input to the hypothalamic paraventricular nucleus of rat. Brain Res 324: 91-99.

180. Suda T, Sato $Y$, Sumitomo T, Nakano $Y$, Tozawa F, Iwai I, Yamada M, Demura H (1992) $\beta$-endorphin inhibits hypoglycemia-induced gene expression of corticotropin-releasing factor in the rat hypothalamus. Endocrinology 130: 1325-1330.

181. Plotsky PM (1986) Opioid inhibition of immunoreactive corticotropin-releasing factor secretion into the hypophysial-portal circulation of rats. Regul Pept 16: 235-242.

182. Buckingham JC (1986) Stimulation and inhibition of corticotrophin releasing factor secretion by beta endorphin. Neuroendocrinology 42: 148-152.

183. Kamilaris TC, Johnson EO, Calogero AE, Kalogeras KT, Bernardini R, Chrousos GP, Gold PW (1992) Cholecystokinin-octapeptide stimulates hypothalamic-pituitary-adrenal function in rats: Role of corticotropin-releasing hormone. Endocrinology 130: 1764-1774.

184. Biro E, Sarnyai Z, Penke B, Szabo G, Telegdy G (1993) Role of endogenous corticotropin-releasing factor in mediation of neuroendocrine and behavioral responses to cholecystokinin octapeptide sulfate ester in rats. Neuroendocrinology 57: 340-345.

185. Larsen PJ, Jessop D, Patel H, Lightman SL, Chowdrey HS (1993) Substance P inhibits the release of anterior pituitary adrenocorticotropin via a central mechanism involving corticotropin-releasing factor-containing neurons in the hypothalamic paraventricular nucleus. J Neuroendocrinol 5: 99-105.

186. Bittencourt JC, Benoit R, Sawchenko PE (1991) Distribution and origins of substance $P$ immunoreactive projections to the paraventricular and supraoptic nuclei: Partial overlap with ascending catecholaminergic projections. J Chem Neuroanat 4: 63-78.

187. Buckingham JC, Cooper TA (1984) Differences in hypothalamo-pituitary-adrenocortical activity in the rat after acute and prolonged treatment with morphine. Neuroendocrinology 38: 411-417.

188. Buckingham JC (1982) Secretion of corticotropin and its hypothalamic releasing factor in response to morphine and opioid peptides. Neuroendocrinology 35: 111-116.

189. Brown MR, Rivier C, Vale W (1984) Central nervous system regulation of adrenocorticotropin secretion: Role of somatostatins. Endocrinology 114: 1546-1549.

190. Sawchenko PE, Benoit R, Brown MR (1988)
Somatostatin 28-immunoreactive inputs to the paraventricular and supraoptic nuclei: Principal origin from non-aminergic neurons in the nucleus of the solitary tract. J Chem Neuroanat 1: 81-94.

191. Tempel DL, Leibowitz SF (1990) Galanin inhibits insulin and corticosterone release after injection into the PVN. Brain Res 536: 353-357.

192. Levin MC, Sawchenko PE, Howe PRC, Bloom SR, Polak JM (1987) Organization of galaninimmunoreactive inputs to the paraventricular nucleus with special reference to their relationship to catecholaminergic afferents. J Comp Neurol 261: 562-582.

193. Plotsky PM, Kjaer A, Sutton SW, Sawchenko PE, Vale W (1991) Central activin administration modulates corticotropin-releasing hormone and adrenocorticotropin secretion. Endocrinology 128: 2520-2525.

194. Sawchenko PE, Plotsky PM, Pfeiffer SW, Cunningham ET Jr, Vaughan J, Rivier J, Vale W (1988) Inhibin $\beta$ in central neural pathways involved in the control of oxytocin secretion. Nature 334: 615 617.

195. Sawchenko PE, Arias C, Bittencourt JC (1990) Inhibin $\beta$, somatostatin, and enkephalin immunoreactivities coexist in caudal medullary neurons that project to the paraventricular nucleus of the hypothalamus. J Comp Neurol 291: 269-280.

196. Mandell AJ, Chapman LF, Rand RW, Walter RD (1963) Plasma corticosteroids: Changes in concentration after stimulation of hippocampus and amygdala. Science 139: 1212-1213.

197. Rubin RT, Mandell AJ, Crandall PH (1966) Corticosteroid responses to limbic stimulation in man: Localization of stimulus sites. Science 153: 767768.

198. Wilson MM, Greer SE, Greer MA, Roberts L (1980) Hippocampal inhibition of pituitary-adrenocortical function in female rats. Brain Res 197: 433-441.

199. Fischette CT, Komisaruk BR, Edinger HM, Feder $\mathrm{HH}$, Siegel A (1980) Differential fornix ablations and the circadian rhythmicity of adrenal corticosteroid secretion. Brain Res 195: 373-387.

200. Herman JP, Schafer MK-H, Young EA, Thompson R, Douglass J, Akil H, Watson SJ (1989) Evidence for hippocampal regulation of neuroendocrine neurons of the hypothalamo-pituitaryadrenocortical axis. J Neurosci 9: 3072-3082.

201. Herman JP, Cullinan WE, Young EA, Akil H, Watson SJ (1992) Selective forebrain fiber tract lesions implicate ventral hippocampal structures in tonic regulation of paraventricular nucleus corticotropin-releasing hormone (CRH) and arginine vasopressin (AVP) mRNA expression. Brain Res 592: 228-238.

202. Reul JMHM, de Kloet ER (1985) Two receptor systems for corticosterone in rat brain: 
Microdistribution and differential occupation. Endocrinology 117: 2505-2511.

203. Fuxe K, Wirkstrom A-C, Okret S, Agnati LF, Harfstrand A, Yu Z-Y, Granholm L, Zoli M, Vale W, Gustafsson J-A (1985) Mapping of glucocorticoid receptor immunoreactive neurons in the rat tel- and diencephalon using a monoclonal antibody against rat liver glucocorticoid receptor. Endocrinology 117: 1803-1812.

204. Herman JP, Patel P, Akil H, Watson SJ (1989) Localization and regulation of glucocorticoid and mineralocorticoid receptor messenger RNAs in the hippocampal formation of the rat. Mol Endocrinol 3: 1886-1894.

205. Sousa RJ, Tannery NH, Lafer EM (1989) In situ hybridization mapping of glucocorticoid receptor messenger ribonucleic acid in rat brain. Mol Endocrinol 3: 481-494.

206. Redgate ES, Fahringer EE (1973) A comparison of the pituitary adrenal activity elicited by electrical stimulation of preoptic, amygdaloid and hypothalamic sites in the rat brain. Neuroendocrinology 12: 334-343.
207. Van de Kar LD, Piechowski RA, Rittenhouse PA, Gray TS (1991) Amygdaloid lesions: Differential effect on conditioned stress and immobilizationinduced increases in corticosterone and renin secretion. Neuroendocrinology 54: 89-95.

208. Gray TS, Carney ME, Magnuson DJ (1989) Direct projections from the central amygdaloid nucleus to the hypothalamic paraventricular nucleus: Possible role in stress-induced adrenocorticotropin release. Neuroendocrinology 50: 433-446.

209. Herman JP, Prewitt CM-F, Cullinan WE (1996) Neural circuit regulation of the hypothalamopituitary-adrenocortical stress axis. Critical Rev Neurobiol 10: 371-394.

210. Feldman S, Conforti N, Itzik A, Weidenfeld J (1994) Differential effect of amygdaloid lesions following neural stimuli. Brain Res 658: 21-26.

211. Herman JP, Cullinan WE, Watson SJ (1994) Involvement of the bed nucleus of the stria terminalis in tonic regulation of paraventricular hypothalamic CRH and AVP mRNA expression. J Neuroendocrinology 6: 433-442. 